\title{
Kommentar
}

\section{Sjelden årsak til alvorlig lidelse}

HACEK er et akronym som refererer til en gruppe taksonomisk ulike bakterier med en rekke fellestrekk. Det står for Haemophilus parainfluenzae, Aggregatibacter (A aphrophilus, A actinomycetemcomitans), Cardiobacterium spp., Eikenella corrodens og Kingella kingae $(1,2)$. Alle disse har en tendens til å forårsake endokarditt, men de var tidligere lite kjent fordi de er vanskelige å få til å vokse. HACEK-endokarditt havnet derfor i gruppen kulturnegative endokarditter. Fremdeles forblir mange av disse endokardittene kulturnegative. Bakteriene er små, gramnegative staver tilhørende den orofaryngeale normalflora og finnes ofte i dentale plakk og tannkjøttslommer. De er kravfulle og vokser langsomt. De fleste trenger minst 48 timer før man kan forvente vekst, enkelte kan kreve 72 timer eller mer. Inkubering i $\mathrm{CO}_{2}-$ anriket atmosfære fremmer vekst.

HACEK-gruppen er en forholdsvis sjelden årsak til endokarditt, men likevel den vanligste årsak til gramnegativ endokarditt hos både barn og voksne som ikke er intravenøse stoffmisbrukere. Hos voksne forårsaker de ca. 3\% av alle endokarditter (1). På grunn av økt oppmerksomhet blir HACEK-endokarditt stadig hyppigere påvist, ev. ved hjelp av molekylærbiologisk teknikk. Om det er en reell økning, er ikke avklart. I perioden 1998-2008 har vi ved Haukeland universitetssykehus funnet HACEK som årsak ved ti av 300 bakteriepositive endokarditter (3\%). Kun én av disse tilhørte genus Cardiobacterium, slik som i Dale og medarbeideres sykehistorie. Hos sprøytemisbrukere og hos pasienter med invasive prosedyrer/sentralvenøse katetere i sykehus er andre gramnegative bakterier en hyppigere årsak til endokarditt. Såkalt ikke-HACEK gramnegativ endokarditt er nå sannsynligvis minst like hyppig som HACEK-endokarditt (3).

Infeksjon i tenner og tannkjøtt utgjør 60\% av alle HACEK-infeksjoner. Vanligst ses periodontale infeksjoner, spesielt periodontitt. Bakteriene har en tendens til å bli invasive og gi abscesser i munnhulen. Andre infeksjoner som sepsis, peritonitt, otitis media, konjunktivitt, pneumoni, septisk artritt, osteomyelitt og hjerneabscesser ses også. Hjerneabscesser med Aggregatibacter er en alvorlig komplikasjon til munnhuleinfeksjoner. Dårlig tannstatus og tannbehandling er predisponerende både for hjerneabscesser og HACEK-endokarditt. Endokarditt ses oftest hos pasienter med oral patologi og patologiske eller kunstige hjerteklaffer.

Dale og medarbeidere beskriver et tilfelle med endokarditt forårsaket av Cardiobacterium valvarum, identifisert med molekylærbiologisk teknikk. Cardiobacterium skiller seg fra de andre i gruppen ved at den nesten utelukkende forårsaker endokarditt, oftest hos pasienter med oral patologi. Cardiobacterium er små gramvariable pleomorfe dråpeformede staver i par, i korte kjeder eller i grupper med rosettform.

Noen HACEK-bakterier produserer $\beta$ laktamaser (Haemophilus og Aggregatibacter). Ampicillin er derfor ikke lenger førstevalg. De er følsomme for tredjegenerasjons kefalosporiner, kvinoloner og aminoglykosider. Standardbehandlingen er derfor ceftriakson $2 \mathrm{~g} \times 1$ i $4-6$ uker. For de ikke- $\beta$-laktamaseproduserende bakteriene er ampicillin $2 \mathrm{~g} \times 4-6$ i $4-6$ uker kombinert med gentamicin i de første to ukene god behandling (4-6).

Stafylokokker er nå den hyppigste årsaken til endokarditt, men viridansstreptokokker er fortsatt den vanligste årsak utgående fra munnhulen. For ikke å overse bakterier fra HACEK-gruppen som kan være penicillinresistente, må man i prøver til mikrobiologiske undersøkelser opplyse at HACEK kan være en mulig årsak, spesielt om pasienten har en oral infeksjon, slik at blodkulturene kan inkuberes tilstrekkelig lenge. Dersom dyrkingen er negativ, er det viktig å anvende molekylærbiologisk teknikk, slik denne sykehistorien viser.

\section{Haakon Sjursen}

haakon.sjursen@helse-bergen.no

Medisinsk avdeling

Haukeland universitetssykehus

5020 Bergen

Oppgitte interessekonflikter: Ingen

Litteratur

1. Berbari EF, Cockerill FR, Steckelberg JM. Infective endocarditis due to unusual or fastidious microorganisms. Clin Proc 1997; 72: 532-42.

2. Norskov-Lauritsen N. Kilian M. Reclassification of Actinobacillus actinomycetemcomitans, Haemophilus aphrophilus, Haemophilus paraphrophilus and Haemophilus segnis as Aggregatibacter actinomycetemcomitans gen. nov., comb. nov. Aggregatibacter aphrophilus comb. nov. and Aggregatibacter segnis comb. nov., and emended description of Aggregatibacter aphrophilus to include $V$ factor-dependent and $V$ factor-independent isolates. Int J Syst Evol Microbiol 2006; 56: 2135-46

3. Morpeth S, Murdoch D, Cabell CH et al. NonHACEK gram negative bacillus endocarditis. Ann Intern Med 2007; 147: 829-35.

4. Sjursen $\mathrm{H}$. Antibiotikabehandling ved infeksiøs endokarditt. Tidsskr Nor Lægeforen 2001; 121: 3300-5.

5. Guidelines on the prevention, diagnosis, and treatment of infective endocarditis of the European Society of Cardiology (ESC). Eur Heart J 2009; 30 2369-413.

6. Baddour LM, Wilson WR, Bayer AS et al. Infective endocarditis: diagnosis, antimicrobial therapy, and management of complications: a statement for healthcare professionals from the Committee on Rheumatic Fever, Endocarditis, and Kawasaki Disease, Council on Cardiovascular Disease in the Young, and the Councils on Clinical Cardiology, Stroke, and Cardiovascular Surgery and Anesthesia, American Heart Association: endorsed by the Infectious Diseases Society of America. Circulation 2005; 111: 3167-84

Manuskriptet ble mottatt 23.12. 2009 og godkjent 4.1. 2010. Medisinsk redaktør Erlend Hem. 